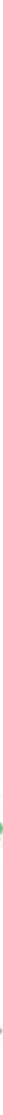

\title{
The globe's green avenger
}

\section{Maurice Strong has shaped how nations respond to planetary crises. Ehsan Masood meets the man whose successes - and failures - laid the groundwork for the current climate talks.}

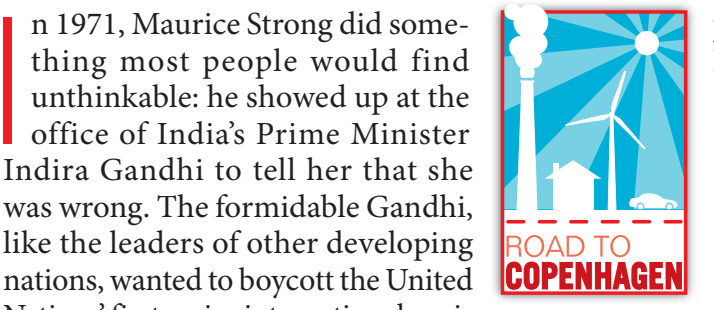

Nations' first major international environmental conference, planned for the following year in Stockholm. The developing nations feared that environmental agreements would undermine their ability to prosper - a concern that still resonates today.

As the leader of the upcoming conference, Strong regarded the developing nations as essential players. So, against the advice of Indian diplomats, he flew to New Delhi and urged Gandhi to drop the boycott and attend the conference as an advocate for the developing world.

"She had a habit of falling silent during conversations and said absolutely nothing for 10 or 12 minutes," Strong recalls. "Now, I've lived among the Inuit, and they, too, fall silent during conversations, although for much longer periods, so this didn't bother me at all. I waited for her reply and when she finally spoke, she said 'yes."

Strong has spent much of his life trying to make the world see matters his way, sometimes by remaining silent but more often through a mixture of negotiation and persuasion. He helped to found the United Nations Environment Programme (UNEP) in 1972. He chaired the 1992 Earth Summit in Rio de Janeiro, Brazil, that produced the first climate treaty. And he mentored a generation of environmental, politi$\mathrm{cal}$ and business leaders around the world.

Many of them gathered in Gland, Switzer-

$$
\begin{aligned}
& \text { "Maurice had this ability to } \\
& \text { reach out and grab world } \\
& \text { leaders by the arm, whether } \\
& \text { they liked it or not." } \\
& \quad \text { - Jonathan Lash }
\end{aligned}
$$
land, this month at the headquarters of the International Union for the Conservation of Nature (IUCN) to celebrate Strong's 80th birthday. It was also an occasion to take stock of the planet and discuss the round of climate negotiations that will conclude in December in Copenhagen. The chances for success in Denmark depend to a large degree on what Strong has accomplished over the past 40 years, and on what he was unable to achieve.
From the beginning, Strong had outsized ambition. Born into poverty in the Canadian town of Oak Lake, Manitoba, at the start of the Great Depression, he writes in his autobiography Where on Earth are We Going? that his childhood dream was to devote his life to the protection of nature and to work for world peace, having lived through the Second World War and seen its effects on humans and on the environment. When the war ended and countries were discussing the establishment of the UN, Strong says, "I wrote in my diary: 'this is where I want to be."”

\section{Ascent of nations}

Strong started at the bottom, working in the office that issues security passes at the UN building in New York. Later he would rise, via posts in the Canadian government and in business, to chair the Stockholm and Rio conferences on the environment. He helped to set up Canada's national oil company Petro Canada as well as its International Development Research Centre, and he led the team that proposed a plan to reform the UN. Strong's childhood instilled a determination never again to be poor, and he grew rich leading various companies and through property investment. In many ways, Strong's greatest legacy is 
the creation of UNEP, which emerged out of the 1972 Stockholm conference and has since played a catalytic part in international environmental issues. The organization oversaw the process that created the Montreal Protocol of 1987, a treaty to phase-out ozone-depleting compounds. In 1988, UNEP joined with the World Meteorological Organization to create the Intergovernmental Panel on Climate Change. Four years later in Rio, UNEP and the environmental movement shaped new international agreements on climate change and biodiversity, and laid the groundwork for a treaty to combat desertification. The climate convention provided the road map for the Kyoto Protocol - in which nations pledged to cut greenhouse-gas emissions - and established the process for the climate talks.

\section{Bridge-building}

For the Stockholm and Rio conferences to succeed, Strong knew he needed to earn the trust of developing countries. But he also built bridges with the scientific and business communities and he opened up both events to participation from non-governmental organizations — often against the wishes of governments.

"Maurice really pushed the door for public engagement," says James Gustave Speth, a former administrator of the UN Development Programme and founder of the World Resources Institute, an environmental think-tank in Washington DC. "You have to remember that this had never happened before and it had ramifications across all other UN processes."

Yet despite Strong's successes in bringing people and nations together, the policy architecture he created has done little so far to make the world safer. Aside from the successful global effort to protect the ozone layer, international environmental agreements have faltered. In particular, they lacked mechanisms to verify whether countries met their commitments or to penalize those that fell short. This led to the anticipated failure of the Kyoto treaty, and will also doom the parallel commitment to slow down the rate of loss of biodiversity by 2010 . The consensus at the meeting in Switzerland was that the fault lies with the current environmental policy structure.

Strong acknowledges that the treaties have suffered because they allowed "governments to say one thing, but do the opposite". The fault may lie with the expectations that Strong and others had. The entire environmental movement had a misplaced confidence in the ability of governments to deliver on their promises, says Speth.

That realization has tempered hopes for the climate negotiations this year, and Strong doubts whether December's Copenhagen climate summit will succeed. "Radical thinking is needed," he says, "but there is no evidence that governments are ready for that." There is no point to an agreement, he says, unless it has "binding real penalties, fines and trade bans that are designed to make agreements enforceable", rather like what happens in the World Trade Organization or the International Atomic Energy Agency.

Another problem with past environmental agreements is the relationship between the richer and poorer countries. Developing nations have long insisted that if they were going to be forced to grow sustainably - unlike the richer nations - then substantial financial support should be made available. But the wealthy nations baulked at that request, in part because they didn't want to be seen as accepting responsibility for global environmental problems. It has taken nearly four decades for a potential solution to emerge. UK Prime Minister Gordon Brown proposed last month to start a climate fund that would give US $\$ 100$-billion to developing countries each year, paid for by the world's wealthiest nations.

A third issue that has dogged Strong is his poor relations with US administrations - and his belief that global agreements can work without the United States. "I did spend a lot of time in America," he says. "But America already had many people who could speak on its behalf. Yes, I could have put more time in, but even the Americans were telling me 'you've got to get the developing countries on side.' I used to

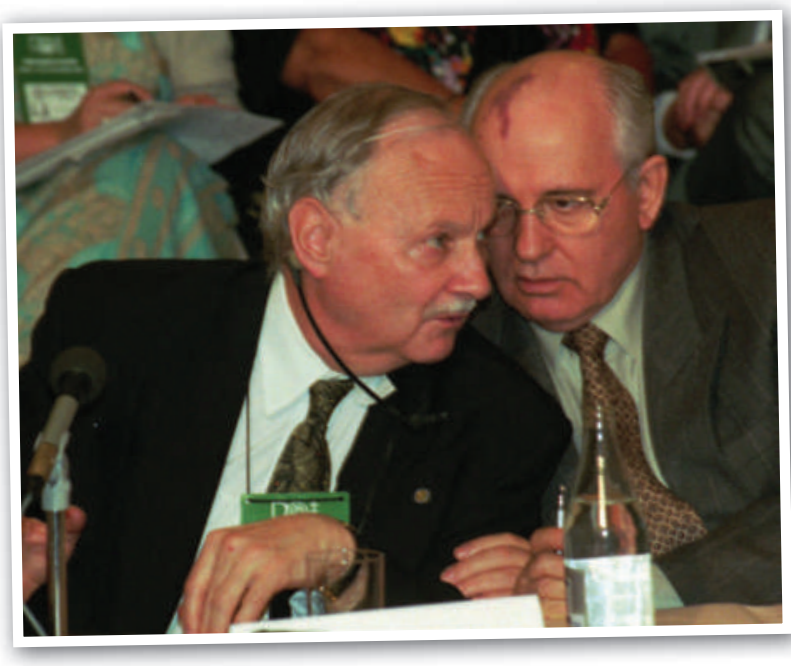

Maurice Strong (left, with former Soviet leader Mikhail Gorbachev) has been able to bring world leaders together. tell the Americans that if I am seen to be in your pocket, then I am of no use to anyone."

To this day, Strong gets bad press in the United States, where reporters often focus on potential conflicts of interest that affected him while he was working in the upper tiers of the UN.

\section{Little black book}

Yet Strong has no shortage of supporters, especially among the world leaders he helped to groom. He has a legendary record in spotting promising individuals, which is evident in the roll-call of people whom he hired early in their careers. Canada's former prime minister Paul Martin, James Wolfensohn, who evidence Kakabadse, former environment minister of Ecuador and now president of the environmental group WWF, and many serving heads of UN agencies are Strong protégés and cite him as a major influence in their lives.

When the IUCN was having financial problems in the 1980s, "Maurice stepped in and came to our rescue", says Julia Marton-Lefèvre, IUCN director-general. "He would make the phone calls or get us a seat at the right table," she says. "Maurice had this ability to reach out and grab world leaders by the arm, whether they liked it or not," says Jonathan Lash, president of the World Resources Institute. "He used his access and networks shamelessly for all of us. Long before iPhones, the net and Twitter, we had Maurice."

At the start of the Rio conference, Strong had insisted (and as usual got his way) on a private meeting between himself, the UN secretarygeneral and more than 100 heads of government, without their minders and attendants. In his address to them, Strong said that the planet had only one real chance, and that they stood between success and failure.

Strong was wrong about the one chance. The Rio climate treaty, and its progeny, did not stop global warming, and there is debate about whether they have reduced the problem in any substantial way. But politics and the climate have evolved since Strong urged leaders towards action. The world has yet another chance in Copenhagen and the outcome depends largely on whether countries have learned from their past mistakes.

Ehsan Masood teaches international science policy at Imperial College London. 